\title{
Penggunaan Media Puzzel Bagi Mahasiswa PGSD FIP UNM Parepare
}

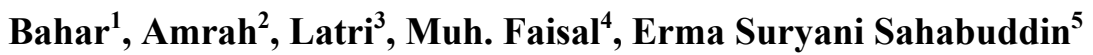 \\ ${ }^{1}$ Program Studi Pendidikan Matematika, Fakultas Keguruan dan Ilmu Pendidikan, Universitas \\ Sawerigading Makassar \\ ${ }^{2,3,4,5}$ Program Studi Pendidikan Sekolah Dasar, Fakultas Ilmu Pendidikan, \\ Unversitas Negeri Makassar \\ 1baharbethatwins@gmail.com, \\ ²amrah@unm.ac.id \\ muh.faisal@unm.ac.id \\ 5 ermasuryani@unm.ac.id
}

\begin{abstract}
ABSTRAK
Tujuan kegiatan yang diinginkan adalah mengenalkan cara-cara penggunaan dan pembuatan alat peraga puzzle sedini mungkin bagi mahasiswa PGSD FIP UNM karena kebanyakan guru sekolah dasar kesulitan dalam mengajarkan matematika, khususnya untuk materi geometri. Hal ini dikarenakan kurangnya ketersediaan media terkhusus media puzzle serta tidak dilengkapi cara penggunaannya. Metode yang digunakan dalam pengabdian adalah penyampaian materi secara ceramah dan demonstrasi, praktik pembuatan alat peraga oleh para peserta, dan praktik simulasi penggunaan alat peraga oleh kelompok-kelompok peserta. Produk yang dihasilkan selama pengabdian adalah media puzzle yang terbentuk dari 7 kepingan bangun datar geometri diantaranya bangun datar geometri yang dipotong menjadi bentuk-bentuk tertentu seperti, Dua segitiga siku-siku sama kaki (besar), Dua segitiga siku-siku sama kaki (kecil), Satu segitiga siku-siku sama kaki (sedang), Satu bujursangkar (kecil), dan Satu jajaran genjang yang dapat dimanipulatif keberbagai bentuk.
\end{abstract}

Kata kunci: Media Puzzel, Mahasiswa

\section{ABSTRACT}

The purpose of the desired activity is to introduce ways to use and make puzzle props as early as possible for PGSD FIP UNM students because most elementary school teachers have difficulty in teaching mathematics, especially for geometry material. This is due to the lack of availability of media, especially puzzle media and not equipped with how to use it. The methods used in the service are the delivery of material through lectures and demonstrations, the practice of making props by the participants, and the practice of simulating the use of teaching aids by groups of participants. The product produced during the service is a puzzle media that is formed from 7 geometric flat shapes including geometric flat shapes cut into certain shapes such as, Two isosceles right triangles (large), Two isosceles right triangles (small), One isosceles right triangle (medium), One square (small), and One parallelogram that can be manipulated into various shapes.

Keywords: Media Puzzle, Student

\section{PENDAHULUAN}

PENDAHULUAN
Matematika merupakan pelajaran
umum yang sangat renting
bagi setiap siswa. Matematika memiliki
begitu banyak rumus yang harus dihafal dan
juga selalu berhubungan dengan angka.
Alat peraga matematika akan
menjadi salah satu hal yang mampu
membantu pembelajaran matematika
dengan efektif. Alat peraga ada begitu
banyak jenis. Semakin kreatif seseorang
untuk memahami ilmu maka akan semakin
bagus juga alat peraga yang mampu dibuat.

Alat peraga akan memberikan pengalaman belajar yang berbeda bagi siswa tidak hanya mendengarkan dan kemudian mencatat saja. Alat peraga akan mampu memberikan contoh konkret dalam penerapan teori. Penggunaan media pembelajaran merupakan unsur yang sangat mendukung peningkatan prestasi belajar siswa di sekolah, karena media merupakan alat bantu dan narasumber belajar dalam proses pembelajaran, sehingga dapat melicinkan jalan menuju tercapainya tujuan pembelajaran. 
Matematika merupakan suatu ilmu yang berhubungan dengan penelaahan bentuk suatu struktur yang abstrak dan hubungan diantara hal-hal tersebut. Satu diantara materi matematika adalah Pecahan. Materi Pecahan yang bersifat abstrak merupakan satu materi yang sulit dipahami oleh siswa SD. Beberapa siswa yang diwawancarai, mengatakan bahwa mereka sering lupa dengan aturan-aturan pada Pecahan, seperti: membandingkan pecahan dan menentukan hasil operasi pecahan yang tidak senama. Selain itu, berdasarkan pengalaman tim pengabdian sebagai pembimbing mahasiswa PPG dan diskusi dengan guru SD, bahwa sebagian besar guru SD mengajarkan Pecahan tanpa menggunakan media. Belum adanya media pembelajaran Pecahan, membuat siswa pasif menerima pengetahuan dari guru dan sulit memahami pecahan. Untuk memahami konsep Pecahan yang abstrak, siswa memerlukan benda-benda kongkret sebagai perantara atau visualisasinya. Berdasarkan hal tersebut, siswa masih harus diberikan kegiatan nyata yang dapat diterima akal mereka. Dengan demikian alat bantu belajar atau biasa disebut media sangatlah diperlukan untuk memberikan pengalaman belajar yang bermakna, mengaktifkan dan menyenangkan.

Oleh karena itu dalam pembelajaran Pecahan diperlukan media/alat peraga. Menurut Piaget, Bruner dan Dienes (Ruseffendi, 1992) dalam pembelajaran matematika, sangat diperlukan alat peraga untuk menerangkan atau mewujudkan konsep matematika bagi siswa SD yang masih pada tahap berpikir pada operasi kongkret. Selain itu, Iswandi (2003) menyatakan bahwa alat peraga matematika adalah seperangkat benda kongret yang dirancang, dibuat, dihimpun, atau disusun secara sengaja yang digunakan untuk membantu menanamkan atau mengembangkan konsep-konsep atau prinsip-prinsip dalam matematika. Dengan alat peraga, maka hal-hal yang abstrak dapat disajikan dalam bentuk model-model, sehingga siswa dapat memanupulasi objek tersebut dengan cara dilihat, dipegang, diraba, diputarbalikan, agar lebih mudah memahami konsep matematika. Pemahaman konsep sangat penting, karena dengan pemahaman konsep akan mempermudah siswa dalam mempelajari matematika khususnya Pecahan. Pada setiap pembelajaran sebaiknya diusahakan lebih ditekankan pada pemahaman konsep agar siswa memiliki bekal dasar yang baik untuk mencapai kemampuan dasar yang lain seperti penalaran, komunikasi dan pemecahan masalah.

Permendikbud No. 65 Tahun 2013 tentang Standar Proses Pendidikan Dasar dan Menengah telah mengisyaratkan tentang perlunya proses pembelajaran yang dipandu dengan kaidah-kaidah pendekatan saintifik/ilmiah. Upaya penerapan Pendekatan saintifik/ilmiah dalam proses pembelajaran ini sering disebut-sebut sebagai ciri khas dan menjadi kekuatan tersendiri dari keberadaan Kurikulum 2013, yang tentunya menarik untuk dipelajari dan dielaborasi lebih lanjut. Guru sebagai salah satu unsur dalam proses belajar mengajar, memiliki pengaruh yang cukup besar terhadap kegiatan belajar mengajar matematika. Oleh karena itu guru harus mampu menciptakan situasi yang dapat menunjang perkembangan belajar siswa. Semua ini tidak terlepas bagaimana guru memiliki kreativitas untuk membuat alat peraga yang sesuai dengan materi yang diajarkan. Setiap guru pasti menginginkan siswanya memahami konsep matematika yang diajarkan dan trampil dalam menggunakannya.

Berdasarkan hal tersebut, sangat diharapkan adanya penyuluhan atau pelatihan sedini mungkin bagi mahasiswa PGSD terkait dengan pembuatan dan penggunaan alat peraga dalam pembelajaran pecahan, sehingga mereka dapat menunjukkan secara konkret konsep Pecahan dan mengaktifkan siswa dalam pembelajaran untuk peningkatan pengetahuan yang akan menjadikannya guru yang propesional ketika mereka nanti sudah mengabdikan diri dimanyarakat.

METODE KEGIATAN

Kegiatan Pengabdian akan dilaksanakan melalui beberapa tahapan 
pelaksanaan kegiatan yang dapat dijelaskan sebagai berikut:

1. Tahap Persiapan

a. Penyiapan lokasi Pengabdian pelatihan.

b. Koordinasi dengan kepala Laboratorium Matematika PGSD FIP UNM

c. Persiapkan materi, alat dan bahan yang dibutuhkan dalam pelatihan.

2. Tahap Pelaksanaa

Pada tahap ini akan dilakukan pelatihan bagaimana penggunaan dan pembuatan alat peraga puzzle pada mahasiswa PGSD FIP UNM dengan cara mandiri dan kelompok. Kemudia hasilnya disimulasikan cara penggunaan alat peraga puzzle yang sudah dibuat.

\section{HASIL \& PEMBAHASAN}

Kegiatan pengabdian pada masyarakat yang dikemas dalam bentuk pelatihan ini dilaksanakan pada tanggal 20 Mei 2019. Banyaknya peserta yang ikut pada kegiatan tersebut adalah 21 orang. Kegiatan dilaksanakan di ruang Laboratorium Matematika PGSD FIP UNM Parepare. Pelatihan diawali dengan penyajian materi tentang penggunaan dan pembuatan media puzzle bagi peserta pelatihan. Media puzzle diperlukan untuk menjembatani pola berpikir siswa SD yang bersifat kongkrit dan semi kongkrit dengan ilmu matematika yang bersifat abstrak. Hal ini mengikuti pendapat Piget (dalam Subarinah, 2006) yang menyatakan bahwa anak usia SD masih berada pada tahap operasi kongkret, sehingga anak SD dalam belajarnya perlu memanipulasi bendabenda nyata sebagai obyek belajarnya. Menurut Bruner (dalam Reys, 1998) anak SD perlu melakukan manipulasi objek, mengkonstruksi, menyusun objek konkrit, berinteraksi secara langsung dengan benda fisik sehingga pada tahap yang lebih tinggi anak mulai mampu menggunakan gambar untuk memahami situasi. Dengan demikian kegiatan pengabdian ini pada akhirnya secara tidak langsung bermanfaat untuk meningkatkan pemahaman siswa terhadap konsep-konsep matematika.
Penyajian materi yang dilakukan dalam kegiatan pengabdian pada masyarakat menggunakan kombinasi metode ceramah, tanya jawab, dan demonstrasi. Tim pengabdian pada masayarakat memulai penyajian materi dengan penjelasan tentang cara pembuatan media puzzle dan penggunaan media puzzle di kelas. Proses kegiatan pengabdian masyarakat bagi peserta pelatihan diberi kesempatan untuk bertanya atau menyampaikan pendapat sehingga terjadi diskusi multiarah yang menjadikan kegiatan lebih efektif sehingga tujuan yang diharapkan tercapai. Adapun diskusi yang terjadi yaitu terjadi peningkatan pengetahuan dan pemahaman peserta tentang pembuatan dan penggunaan media puzzle.

Aktivitas peserta kegiatan pengabdian dalam pembuatan media puzzle terlihat sangat antusias. Peserta dibagi dalam 5 kelompok, kemudian diberi tugas untuk membuat media puzzle manipulatif yang berbentuk 7 bangun datar geometri yang dipotong menjadi bentuk-bentuk tertentu seperti, Dua segitiga siku-siku sama kaki (besar), Dua segitiga siku-siku sama kaki (kecil), Satu segitiga siku-siku sama kaki (sedang), Satu bujursangkar (kecil), dan Satu jajaran genjang. Potonganpotongan bangun datar tersebut nantinya akan disusun kembali untuk membentuk bangun geometri lain atau menyerupai bentuk binatang, orang huruf dan bentuk apa saja yang dapat dipikirkan.

Berdasarkan kegiatan pengabdian masyarakat dari setiap kelompok peserta memperagakan penyusunan bangun baru berbagai macam bentuk, terdapat kelompok yang memanipulatif media fuzzle kedalam bentuk angsa, kelinci, Huruf R, Pesat, bangunan dan banyak bentuk lainnya yang dapat diperagakan dari berbagai macam bentuk dari setiap kelompok.

Adapun manfaat media puzzle selama kegiatan berlangsung yaitu memberikan pengalaman kepada peserta untuk menggunakan permainan ini sebagai media pembelajaran guna membentuk pengertian akan ide-ide geometri, juga mengembangkan kemampuan spasial. 
Mereka dapat menggerakkan kepingankepingan puzzle untuk menyadari relasi bentuk geometri tiap keping, dan juga mempelajari mengenai pembalikan, pemindahan dan perputaran. Hal ini memberikan gambaran nyata bagi mereka yang orientasi belajarnya adalah melalui penglihatan (visual). Dengan memindahkan-mindahkan ketujuh kepingan yang ada, kita dapat menciptakan berbagai bentuk yang sangat banyak. Ini adalah awal mula / dasar untuk mengerti akan luas (area) dan garis keliling. Kongruensi, persamaan dan simetri juga dapat dipelajari menggunakan puzzle. Kita bahkan juga dapat menggunakan Tangram untuk menghitung luas tanpa menggunakan rumus. Seiring dengan pendapat Para ahli mengatakan bahwa puzzle (Tangram) bermanfaat bagi anak-anak dalam berbagai hal, di antaranya (Bohning and Althouse 1997; Krieger 1991; National Council of Teacher's Mathematics 2003) :

- Mengembangkan rasa suka terhadap geometri

- Mampu membedakan berbagai bentuk

- Mengembangkan perasaan intuitif terhadap bentuk-bentuk dan relasirelasi geometri

- Mengembangkan kemampuan rotasi spasial

- Mengembangkan kemampuan pemakaian kata-kata yang tepat untuk memanipulasi bentuk (misalnya membalik', 'memutar', 'menggeser')

- Mempelajari apa artinya 'kongruen' (bentuk yang sama dan sebangun)

Selain itu, Tangram dapat juga menjadi pengalaman multi-kultural bagi para pelajar. Ada beberapa kegiatan seni bahasa yang berpusat seputar Tangram, sehingga di sini terjadi hubungan interdisipliner bidang ilmu

Oleh karena itu, selama kegitan berlangsung berdasar dari hasil pengamatan selama pelatihan nampak bahwa sekitar $85 \%$ peserta pelatihan telah mampu memperlihatkan peningkatan yang signifikan, sedangkan sisanya masih perlu mendapatkan latihan tambahan agar mereka bisa memanipulatif media puzzle kedalam berbagai bentuk. Hal tersebut didukung dengan hasil wawancara lepas dengan para peserta, sebagian besar mengatakan bahwa kegiatan pengabdian ini sangat bermanfaat buat mereka. Pengetahuan dan keterampilan yang didapatkan dalam pelatihan tersebut akan mereka aplikasikan ketiga mereka mengaplikasikan ilmu mereka dimasyarakat nantinya.

\section{KESIMPULAN \& SARAN}

Kegiatan pengabdian pada

masyarakat ini telah efektif untuk meningkatkan pengetahuan dan keterampilan dalam membuat dan menggunakan media puzzle sebagai bekal untuk mengajar pada sekolah dasar. Hal ini ditunjukkan dengan kehadiran seluruh peserta sebanyak 21 orang peserta, aktivitas peserta dalam diskusi, pembuatan, dan presentasi penggunaan alat peraga berlangsung sangat komunikatif serta sebesar $85 \%$ peserta pelatihan telah mampu memperlihatkan peningkatan yang signifikan.

Saran dari kegiatan pengabdian pada masyarakat ini yaitu:

1. Pembuatan media puzzle dapat meningkatkan kompetensi peserta dengan memahami cara menggunakannya.

2. Pelatihan pembuatan media puzzle masih perlu ditingkatkan kuantitas pelaksanaannya, terutama untuk materi geometri kelas rendah dan kelas tinggi, serta materi matematika lainnya.

\section{DAFTAR PUSTAKA}

Departemen Pendidikan Nasional. 2003. Undang-undang Republik Indonesia Nomor 20 Tahun 2003 Tentang Sistem Pendidikan Nasional. Jakarta: Departemen Pendidikan Nasional.

Iswandi, D. (2003). Pengembangan Media atau Alat Peraga Pembelajaran Matematika. Makalah (Tidak diterbitkan).

Russeffendi. (1992). Belajar dan FaktorFaktor yang Mempengaruhinya Jakarta: Rineka Cipta 